\title{
Kecernaan, fermentabilitas dan produksi protein ruminal pelepah sawit yang difermentasi dengan isolat mikrobia rumen kerbau secara in vitro
}

\author{
Limbang Kustiawan Nuswanatara *, Eko Pangestu, Sunarso Sunarso, Marry Christiyanto \\ Program Studi Peternakan, Fakultas Peternakan dan Pertanian, Universitas Diponegoro, Semarang, 50275 \\ *Correspondence: limbang.kn@gmail.com
}

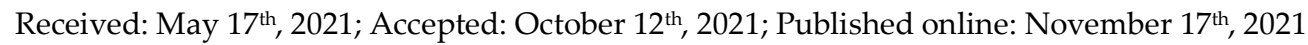

Abstrak

Tujuan: Penelitian bertujuan untuk mengkaji pengaruh level isolat mikrobia dan lama fermentasi terhadap fermentabilitas berupa produksi $\mathrm{NH}_{3}$, volatile fatty acids (VFA) dan produksi protein mikrobia, kecernaan bahan kering (KcBK) dan kecernaan bahan organik (KcBO) secara in vitro.

Metode: Penelitian dilaksanakan di Laboratorium Ilmu Nutrisi dan Pakan, Fakultas Peternakan dan Pertanian, Universitas Diponegoro, Semarang. Penelitian dilakukan secara in vitro, menggunakan rancangan acak lengkap pola faktorial dengan 2 faktor perlakuan dan 4 ulangan. Perlakuan yang digunakan adalah level isolat mikrobia (1 dan 3\%) dan level lama fermentasi (14 dan 28 hari). Variabel yang diamati meliputi produksi $\mathrm{NH}_{3}, \mathrm{VFA}$, protein mikrobia dan protein total serta kecernaan nutrien yang meliputi KcBK dan KcBO. Data hasil penelitian dianalisis ragam dan jika terdapat pengaruh nyata perlakuan dilanjutkan Duncan's Multiple Range Test.

Hasil: Hasil penelitian menunjukan bahwa terdapat interaksi antara faktor level isolat mikrobia dan lama fermentasi terhadap produksi amonia rumen. Namun demikian tidak ada pengaruh interaksi antara faktor level isolate dan lama fermentasi pada produksi volatile fatty acids, produksi protein mikrobia, produksi protein total, kecernaan bahan kering dan kecernaan bahan organik. Perlakuan level isolat mikrobia dan lama fermentasi secara terpisah berpengaruh nyata $(\mathrm{P}<0,05)$ terhadap produksi protein mikrobia rumen. Produksi VFA dan kecernaan bahan kering nyata $(\mathrm{P}<0,05)$ dipengaruhi oleh lama fermentasi, sedangkan perlakuan level isolat dan lama fermentasi tidak memberikan pengaruh nyata terhadap produksi protein total dan kecernaan bahan organik.

Kesimpulan: Pengolahan pelepah sawit melalui proses fermentasi dengan menggunakan isolat mikrobia selulolitik rumen kerbau mampu meningkatkan nilai nutrien pelepah sawit.

Kata Kunci: in vitro; fermentasi; kecernaan; pelepah sawit; volatil fatty acids

\section{Abstract}

Objective: The study aimed investigated effect of microbial isolate levels and fermentation time on fermentability regarding ammonia $\left(\mathrm{NH}_{3}\right)$ production, volatile fatty acids (VFA) and microbial protein production, dry matter digestibility and organic matter digestibility in vitro.

Methods: The experiment was conducted at the Laboratory of Nutrition and Feed Science, Faculty of Animal and Agricultural Sciences, Universitas Diponegoro. In vitro experiment was performed using a completely randomized design with a factorial pattern with 2 factors and 4 replications. The treatments were microbial isolate levels (1 and 3\%) and fermentation time (14 and 28 days). 
The parameters observed included production of $\mathrm{NH}_{3}, \mathrm{VFA}$, microbial protein and total protein as well as the digestibility of dry matter and organic matter. The data were analyzed based on analysis of variance and if there was a significant effect the data were further analyzed with Duncan's Multiple Range Test.

Results: The amount of microbial isolate and fermentation time affected rumen ammonia production. On rumen microbial protein content, the amounts of microbial isolate and fermentation time had substantial impact $(\mathrm{P}<0.05)$. The isolate level and fermentation time, however, had no interaction effect on VFA production, dry matter digestibility, or organic matter digestibility. The fermentation time influenced $(\mathrm{P}<0.05)$ the production of VFA and the digestibility of dry matter, but the isolate level and fermentation time had no effect on total protein production or organic matter digestibility.

Conclusions: Processing of palm fronds through fermentation using buffalo rumen cellulolytic microbial isolates increased nutrient values of palm fronds.

Keywords: digestibility; in vitro; fermentation; palm fronds; volatil fatty acids

\section{PENDAHULUAN}

Pakan merupakan faktor penentu keberhasilan suatu usaha peternakan, oleh sebab itu penyediaan pakan yang berkualitas dan kontinyu sepanjang tahun harus dilakukan untuk meningkatkan produktivitas ternak. Oleh karena itu, perlu dicari sumber bahan pakan alternatif yang potensial untuk dimanfaatkan sebagai pakan ternak. Pelepah sawit merupakan salah satu hasil samping perkebunan kelapa sawit yang potensial digunakan sebagai pakan ternak dan belum dimanfaatkan secara optimal. Jumlah yang melimpah dengan kandungan nutrien yang ada dalam pelepah sawit, dapat dijadikan sebagai bahan pakan berserat bagi ruminansia.

Perkebunan kelapa sawit di Indonesia seluas 12,76 juta ha pada tahun 2018 dengan produksi bahan kering mencapai 36.594 .813 ton/tahun. Jumlah pelepah sawit yang dihasilkan cukup banyak dan sangat potensial digunakan sebagai sumber serat atau pengganti pakan hijauan. Komposisi nutrien pelepah sawit adalah $26,07 \%$ bahan kering, $3,07 \%$ protein kasar, 50,94\% serat kasar, 1,07\% lemak kasar, 39,82\% bahan ekstrak tanpa nitrogen, 5,10\% abu, 0,96\% Ca, 0,08\% P dan energi bruto $4,841 \mathrm{kkal} / \mathrm{kg}$ [1].

Pelepah sawit tidak dapat diberikan sebagai pakan ternak secara tunggal, karena terdapat beberapa kelemahan diantaranya adalah kandungan serat yang tinggi dan berikatan dengan lignin serta kadar protein kasar yang rendah. Kadar lignin pada pelepah sawit dilaporkan sebesar 25,35\% [2]. Kadar lignin pelepah sawit yang tinggi mencapai lebih dari 20\% dari biomassa kering, menyebabkan rendahnya kecernaan pelepah sawit dan menjadi faktor pembatas pemanfaatan pelepah sawit sebagai pakan [2].

Peningkatan nilai cerna dari komponen serat dapat dilakukan melalui fermentasi dengan memanfaatkan kerja bakteri lignoselulolitik dari rumen kerbau. Hal ini didasarkan bahwa karakteristik bakteri pencerna serat dari rumen kerbau yang lebih efisien dalam melakukan degradasi komponen serat, sehingga kecernaan pakan pada kerbau lebih baik dibandingkan pada sapi. Hal ini di duga karena populasi mikroba selulolitik pada rumen kerbau lebih tinggi [3]. Isolasi bakteri lignoselulolitik dari cairan rumen kerbau perlu dilakukan untuk memperoleh isolate tersebut [4].

Evaluasi secara biologis suatu bahan pakan pada ruminansia dapat dilakukan dengan pengukuran fermentabilitas dan kecernaannya dalam rumen secara in vitro merupakan salah satu indikator utama penentu kualitas suatu ransum. Tingkat fermentabilitas bahan pakan dalam rumen oleh mikrobia rumen dapat diketahui melalui produksi amonia $\left(\mathrm{NH}_{3}\right)$, VFA, protein mikrobia dan protein total secara in vitro. Amonia adalah hasil dari degradasi protein dalam rumen yang mencerminkan aktivitas dan populasi mikrobia rumen [5]. VFA merupakan hasil degradasi karbohidrat didalam rumen oleh mikroba yang selanjutnya merupakan indikator 
ketersediaan energi untuk sintesis protein mikrobia. Pamungkas et al. [6] menyatakan bahwa sumber protein yang dapat dimanfaatkan oleh ternak berasal dari protein mikroba dengan protein pakan yang lolos degradasi dalam rumen. Protein pakan yang lolos dari degradasi mikroba rumen yang tercampur dengan protein mikroba disebut juga dengan protein total. Sintesis protein mikroba membutuhkan $\mathrm{NH}_{3}$ sebagai sumber $\mathrm{N}$ dan asam a-keto sebagai kerangka karbon. Peningkatan protein total dapat terjadi jika protein hasil fermentasi mudah didegradasi oleh mikrobia rumen untuk disintesis menjadi protein mikrobia, hal ini harus didukung dengan ketersediaan VFA, dan nutrien lainnya yang optimal dalam rumen [7]. Berdasarkan hal tersebut diduga kombinasi perlakuan level isolat mikrobia dari cairan rumen kerbau dan lama pemeraman dapat meningkatkan fermentabilitas dalam rumen serta akan meningkatkan nilai kecernaan nutrien bahan pakan.

\section{MATERI DAN METODE}

\section{Waktu dan lokasi penelitian}

Penelitian dilakukan pada bulan Maret September 2019, di Laboratorium Ilmu Nutrisi dan Pakan, Fakultas Peternakan dan Pertanian Universitas Diponegoro Semarang. Penelitian dilaksanakan melalui 3 tahap. Tahap Pertama, pembuatan inokulum isolat mikrobia dari cairan rumen kerbau. Cairan rumen kerbau yang baru diambil dari RPH diinkubasi pada suhu $39^{\circ} \mathrm{C}$ selama 16 jam dengan menambahkan $1 \%$ avicel dan $2 \%$ glukosa. Isolasi dilakukan dengan menggunakan $50 \mathrm{ml}$ medium selektif cair dimasukkan ke dalam tabung erlenmeyer yang telah berisi substrat, kemudian menambahkan $2 \%$ cairan rumen kerbau yang telah diinkubasi dengan dialiri gas $\mathrm{CO}_{2}$. Tabung erlenmeyer ditutup rapat dan diinkubasi pada suhu $39^{\circ} \mathrm{C}$ selama 6 hari [8]. Kultur hasil biakan disimpan di lemari pendingin selama dua minggu, kemudian direinokulasi pada medium cair selama 16 jam untuk digunakan sebagai inokulum pada proses fermentasi. Proses fermentasi pelepah sawit dilakukan dengan menambahkan $0,5 \%$ urea sebagai sumber $\mathrm{N}$ dan menggunakan berbagai level mikrobia cairan rumen kerbau per berat kering pelepah sawit. Level mikrobia yang digunakan adalah $1 \%$ (P1) dan 3\% (P2) pada kadar air $70 \%$ dan lama pemeraman 14 hari (H1) dan 28 hari (H2). Kandungan nutrien pelepah sawit fermentasi diukur komponen proksimat dan serat (NDF dan ADF) berdasarkan metode Association of Official Analytical Chemist (AOAC) [9]. Kandungan nutrien pelepah sawit fermentasi selengkapnya disajikan pada Tabel 1.

Penelitian tahap ketiga yaitu analisis fermentabilitas yang meliputi produksi $\mathrm{NH}_{3}$, VFA, protein mikrobia dan produksi protein total dan analisis kecernaan nutrien yang meliputi KcBK dan $\mathrm{KcBO}$ secara in vitro menggunakan metode [10]. Pengukuran produksi VFA dan $\mathrm{NH}_{3}$ menggunakan sampel

Tabel 1. Kandungan Nutrien Pelepah Sawit Fermentasi dengan Level Isolat dan Lama Peram yang Berbeda

\begin{tabular}{lcccc}
\hline \multirow{2}{*}{ Parameter } & \multicolumn{4}{c}{ Kombinasi Perlakuan } \\
\cline { 2 - 5 } & P1H1 (\%) & P2H1 (\%) & P1H2 (\%) & P2H2 (\%) \\
\hline Air & 25,01 & 24,72 & 24,82 & 24,91 \\
Abu & 3,76 & 3,49 & 3,78 & 3,80 \\
Protein Kasar & 1,86 & 2,07 & 2,34 & 2,61 \\
Lemak Kasar & 3,98 & 4,61 & 4,47 & 4,85 \\
Serat Kasar & 43,32 & 44,16 & 44,87 & 44,89 \\
BETN & 47,45 & 45,72 & 44,85 & 43,88 \\
NDF & 88,12 & 87,82 & 86,61 & 86,78 \\
ADF & 72,85 & 70,10 & 73,27 & 72,28 \\
Lignin & 42,09 & 34,90 & 42,41 & 46,17 \\
Selulosa & 31,10 & 39,50 & 26,56 & 34,77 \\
Hemiselulosa & 14,10 & 15,00 & 13,73 & 14,23 \\
\hline
\end{tabular}

$\mathrm{BETN}=$ Bahan Ekstrak Tanpa Nitrogen; $\mathrm{NDF}=$ neutral detergent fiber $; \mathrm{ADF}=$ acid detergent fiber 
pada inkubasi selama 3 jam. Produksi VFA diukur dengan metode destilasi uap dan $\mathrm{NH}_{3}$ diukur dengan metode mikro difusi Conway [11].

Analisis produksi protein total menggunakan metode Kjehdal [9], digunakan endapan yang didapat dari suspensi pelepah sawit fermentasi yang diinkubasi dalam cairan rumen domba. Suspensi diendapkan dengan menggunakan larutan campuran Trichloroacetic acid (TCA) 20\% dan sulfosalicylic acid (SSA) 2\% melalui proses sentrifuge dengan kecepatan $12.000 \mathrm{rpm}$ selama 20 menit.

Pengukuran produksi protein mikrobia rumen in vitro menggunakan sampel dengan lama inkubasi 48 jam, yang disentrifuge dengan kecepatan $3000 \mathrm{rpm}$ selama 20 menit untuk memisahkan antara supernatan dan endapannya, dengan asumsi bahwa mikrobia belum sempurna mengendap dengan pelepah sawit fermentasi. Supernatan hasil sentrifuge digunakan untuk mengukur produksi protein mikrobia rumen dengan metode Lowry, dan diukur absorbansinya pada spektrofotometer dengan standar Bovine serum albumin (BSA).

Penentuan nilai kecernaan bahan kering dan kecernaan bahan organic menggunakan metode [8], menggunakan sampel pelepah sawit sebanyak 0,55 - 0,56 gram yang dimasukkan dalam tabung fermentor, kemudian ditambah dengan larutan saliva buatan (larutan McDougall) sebanyak $40 \mathrm{ml}$ dan cairan rumen domba $10 \mathrm{ml}$. Kemudian diinkubasi kedalam waterbath bersuhu $39^{\circ} \mathrm{C}$ dengan durasi 48 jam. Pengojokan selama 6 jam sekali untuk meningkatkan kontak enzim dan substratnya. Setelah 48 jam diangkat kemudian didinginkan. Untuk memisahkan supernatan dan endapan tabung disentrifuse dengan kecepatan 3000 rpm selama 10 menit. Pencernaan secara enzimatis dilakukan dengan cara menambahkan endapan dengan larutan pepsin $\mathrm{HCl}$ sebanyak $50 \mathrm{ml}$. Kemudian diinkubasi dalam suasana anaerob selama 48 jam, selama inkubasi juga dilakukan penggojokan selama 6 jam sekali. Residu diambil dengan menyaring melalui kertas saring Whatman no 41. Sebagai kontrol digunakan cairan rumen tanpa pelepah sawit perlakuan. Residu dioven pada suhu $105^{\circ} \mathrm{C}$ selama 12 jam, kemudian residu dimasukkan dalam eksikator selama 15 menit dan dilakukan penimbangan, kecernaan bahan kering dapat diketahui dengan rumus Equation 1.

Penentuan KcBO dilakukan dengan memasukkan residu kedalam tanur pada suhu $600^{\circ} \mathrm{C}$ selama 6 jam, kemudian dihitung bobot bahan organiknya. Kecernaan bahan organik dihitung dengan rumus sebagai berikut Equation 2.

$$
\operatorname{KcBK}(\%)=\frac{B K \text { awal }-(B K \text { residu }- \text { BK blanko })}{\text { BK awal }} \times 100
$$

Keterangan: BK = Bahan Kering, KcBK = Kecernaan Bahan Kering

$$
\mathrm{KcBO}(\%)=\frac{\mathrm{BO} \text { awal }-(\mathrm{BO} \text { residu }-\mathrm{BO} \text { blanko })}{\mathrm{BO} \text { awal }} \times 100
$$

Keterangan: $\mathrm{BO}=$ Bahan Organik, $\mathrm{KcBO}=$ Kecernaan Bahan Organik

\section{Analisis data}

Data Fermentabilitas dan kecernaan nutrien dianalisis menggunakan analisis ragam, jika hasil analisis ragam menunjukkan pengaruh nyata $(\mathrm{p}<0,05)$ antar perlakuan, maka untuk mengetahui perbedaan antar perlakuan dilanjutkan dengan Uji jarak berganda Duncan. Analisis data menggunakan program SPSS Versi 24.

\section{HASIL}

Pengaruh perlakuan level isolat dan lama fermentasi terhadap produksi $\mathrm{NH}_{3}$, VFA, protein mikrobia rumen dan protein total

Terdapat pengaruh interaksi $(\mathrm{P}<0,05)$ antara perlakuan penambahan level isolat mikrobia selulolitik rumen kerbau dan lama fermentasi yang berbeda pada pelepah sawit terhadap produksi amonia $\left(\mathrm{NH}_{3}\right)$ rumen. 
Hal ini menunjukkan bahwa kedua faktor perlakuan pada proses fermentasi pelepah sawit saling mempengaruhi dalam produksi amonia $\left(\mathrm{NH}_{3}\right)$ rumen. Kombinasi perlakuan penambahan level isolat mikrobia $3 \%$ dan lama fermentasi 28 hari ( $\mathrm{P} 2 \mathrm{H} 2)$, menghasilkan produksi $\mathrm{NH}_{3}$ rumen terbesar $(\mathrm{P}<0,05)$ yaitu $8,34 \mathrm{mM}$, dibandingkan dengan ketiga kombinasi perlakuan fermentasi lainnya. Perlakuan fermentasi dengan menggunakan level isolat mikrobia sebesar $1 \%$ (P1) menunjukkan tidak adanya peningkatan produksi $\mathrm{NH}_{3}$ rumen secara in vitro, seiring lamanya proses fermentasi yaitu dari 14 hari (H1) menjadi 28 hari (H2), masing-masing sebesar 6,48 mM dan 6,31 mM. Selengkapnya rerata hasil penelitian dapat dilihat pada Tabel 2.

Hasil penelitian menunjukkan tidak terdapat pengaruh interaksi antara perlakuan level isolat dan lama fermentasi terhadap produksi VFA pelepah sawit fermentasi. Hal ini menunjukkan bahwa proses fermentasi oleh bakteri selulolitik baik pada perlakuan level isolat $1 \%$ (P1) dan $3 \%$ (P2) dengan lama fermentasi 14 hari (H1) dan 28 hari (H2) belum mampu saling mempengaruhi produksi VFA.

Hasil penelitian menunjukkan bahwa, kombinasi perlakuan penambahan level isolat mikrobia selulolitik rumen kerbau hingga 3\% dan lama fermentasi hingga 28 hari tidak menunjukkan adanya pengaruh interaksi, namun faktor penambahan level isolat mikrobia dan lama fermentasi berpengaruh nyata $(\mathrm{p}<0,05) \quad$ terhadap produksi protein mikrobia rumen.

Tidak ada pengaruh interaksi antara perlakuan penambahan level isolat mikrobia selulolitik rumen kerbau dan lama fermentasi pada pelepah sawit terhadap peningkatan produksi protein total. Penambahan berbagai level isolat mikrobia selulolitik rumen kerbau dan perbedaan lama fermentasi tidak memberikan pengaruh terhadap produksi protein total.

\section{Pengaruh perlakuan level isolat dan lama fermentasi terhadap kecernaan bahan kering pelepah sawit}

Tidak terdapat pengaruh interaksi antara perlakuan level isolat dan perbedaan lama fermentasi terhadap KcBK pelepah sawit fermentasi. Level isolat hingga 3\% dan lama fermentasi hingga 28 hari belum saling memberikan dampak pada KcBK. Data KcBK dan KcBO Pelepah sawit fermentasi disajikan pada Tabel 3.

Berdasar Tabel 3. menunjukkan bahwa tidak terdapat pengaruh interaksi antara perlakuan level isolat dan lama fermentasi. Peningkatan pemberian level isolat mikrobia sampai $3 \%$ dengan lama fermentasi 28 hari menunjukkan mikrobia belum mampu mendegradasi bahan-bahan organik secara sinergis, terutama selulosa dan hemiselulosa, sehingga kadar bahan organik yang dihasilkan belum optimal meskipun durasi

Tabel 2. Pengaruh perlakuan Level Isolat dan lama Fermentasi terhadap Produksi $\mathrm{NH}_{3}$, VFA, Protein Mikrobia Rumen dan Protein Total

\begin{tabular}{|c|c|c|c|c|}
\hline \multirow{2}{*}{ Perlakuan } & \multicolumn{4}{|c|}{ Parameter } \\
\hline & $\mathrm{NH}_{3}(\mathrm{mM})$ & VFA (mM) & Protein Mikroba $(\mathrm{mg} / \mathrm{ml})$ & Protein Total $(\mathrm{mg} / \mathrm{ml})$ \\
\hline \multicolumn{5}{|c|}{ Level Isolat $x$ Lama Fermentasi } \\
\hline P1H1 & $6,48 \pm 0,11^{\mathrm{b}}$ & $114,25 \pm 11,17^{\mathrm{ns}}$ & $35,83 \pm 1,96^{\mathrm{ns}}$ & $35,83 \pm 1,96^{\mathrm{ns}}$ \\
\hline P1H2 & $6,31 \pm 0,25^{b}$ & $94,75 \pm 12,07 \mathrm{~ns}$ & $32,55 \pm 5,79$ ns & $32,55 \pm 5,79^{\text {ns }}$ \\
\hline P2H1 & $6,51 \pm 0,25^{\mathrm{b}}$ & $126,50 \pm 15,83^{\text {ns }}$ & $23,02 \pm 0,56^{\mathrm{ns}}$ & $39,60 \pm 8,86^{\mathrm{ns}}$ \\
\hline $\mathrm{P} 2 \mathrm{H} 2$ & $8,34 \pm 0,48^{a}$ & $126,00 \pm 17,43^{\text {ns }}$ & $7,66 \pm 0,56^{\mathrm{ns}}$ & $39,96 \pm 3,85^{\mathrm{ns}}$ \\
\hline \multicolumn{5}{|l|}{ Level Isolat } \\
\hline P1 & $6,40 \pm 0,19 b$ & $104,50 \pm 14,98^{\mathrm{b}}$ & $16,96 \pm 0,19 a$ & $34,19 \pm 4,37^{\mathrm{ns}}$ \\
\hline P2 & $7,42 \pm 1,05^{\mathrm{a}}$ & $126,25 \pm 15,22^{a}$ & $15,34 \pm 1,05^{b}$ & $39,78 \pm 6,32^{\text {ns }}$ \\
\hline \multicolumn{5}{|c|}{ Lama Fermentasi } \\
\hline H1 & $6,50 \pm 0,19 b$ & 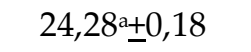 & $24,28 \pm 0,18^{a}$ & $37,72 \pm 6,27 \mathrm{~ns}$ \\
\hline $\mathrm{H} 2$ & $7,32 \pm 1,05^{\mathrm{a}}$ & $8,02^{\mathrm{b}} \pm 1,14$ & $8,02 \pm 1,14^{\mathrm{b}}$ & $36,26 \pm 6,03^{\text {ns }}$ \\
\hline
\end{tabular}


Tabel 3. Pengaruh perlakuan Level Isolat dan lama Fermentasi terhadap Produksi $\mathrm{NH}_{3}$, VFA, Protein Mikrobia Rumen dan Protein Total

\begin{tabular}{lcc}
\hline \multirow{2}{*}{ Perlakuan } & \multicolumn{2}{c}{ Parameter } \\
\cline { 2 - 3 } & KcBK $(\%)$ & KcBO $(\%)$ \\
\hline Level Isolat x Lama Fermentasi & & \\
P1H1 & $40,13+1,26$ & $41,76 \pm 0,11^{\text {ns }}$ \\
P1H2 & $41,58+2,48$ & $41,76 \pm 1,19^{\text {ns }}$ \\
P2H1 & $37,68+0,78$ & $41,27 \pm 0,17^{\mathrm{ns}}$ \\
P2H2 & $41,22+1,34$ & $41,02 \pm 1,19^{\mathrm{ns}}$ \\
Level Isolat & & \\
P1 & $40,86 \pm 1,97^{\mathrm{ns}}$ & $41,76+0,78^{\mathrm{ns}}$ \\
P2 & $39,45 \pm 2,14^{\mathrm{ns}}$ & $41,15+0,79^{\mathrm{ns}}$ \\
Lama Fermentasi & & \\
H1 & $38,91 \pm 1,63^{\mathrm{b}}$ & $41,52+0,29^{\mathrm{ns}}$ \\
H2 & $41,40 \pm 1,85^{\mathrm{a}}$ & $41,33+1,15^{\mathrm{ns}}$ \\
\hline
\end{tabular}

a,b superskrip yang berbeda pada kolom yang sama menunjukkan perbedaan yang nyata $(\mathrm{P}<0,05)$. ${ }^{\mathrm{ns}}($ non signifikan $)=$ menunjukkan tidak berbeda nyata $(\mathrm{P}>0,05)$. P1 = Level Isolat $1 \% ; \mathrm{P}_{2}=$ Level Isolat $3 \% ; \mathrm{H}_{1}=$ Lama Fermentasi 14 hari; $\mathrm{H}_{2}=$ Lama Fermentasi 28 hari

fermentasi semakin lama. Demikian pula perlakuan level isolat dan lama fermentasi secara terpisah masing-masing tidak terdapat pengaruh nyata terhadap kecernaan bahan organik.

\section{PEMBAHASAN}

Rerata produksi $\mathrm{NH}_{3}$ rumen berkisar 6,31 $\mathrm{mM}-8,34 \mathrm{mM}$, sejalan yang dilaporkan [12] produksi NH3 pelapah sawit yang difermentasi menggunakan aspergillus niger berkisar 5,79-6,33 mM dan Mardalena et al. [13], melaporkan konsentrasi $\mathrm{NH}_{3}$ sebesar 7,10-7,11 mM. pada pelepah sawit yang difermentasi dengan prolinas. Yuan et al. [14] menyatakan untuk pertumbuhan mikrobia rumen yang optimal dibutuhkan kosentrasi $\mathrm{NH}_{3}$ sebesar 4-21 mM.

Perlakuan fermentasi dengan level isolat mikrobia 3\% (P2) menunjukkan peningkatan $(\mathrm{P}<0,05)$ produksi $\mathrm{NH}_{3}$ rumen, dengan semakin lama proses fermentasi yang dilakukan dari 14 hari (H1) menjadi 28 hari (H2). Hal ini dapat dilihat dari terjadinya peningkatan produksi $\mathrm{NH}_{3}$ rumen menjadi 6,51 $\mathrm{mM}$ dan 8,34 mM. Produksi $\mathrm{NH}_{3}$ yang meningkat dipengaruhi kandungan PK pada Tabel 1. Kandungan PK yang tinggi dengan tingkat degradasi yang tinggi menyebabkan makin banyak protein yang terdegradasi, sehingga konsentrasi $\mathrm{NH}_{3}$ di dalam rumen menjadi tinggi [15].
Tidak terdapat pengaruh interaksi pada rerata produksi VFA diduga, karena kadar serat kasar baik pada pemberian level isolat mikrobia dengan lama fermentasi juga tidak terjadi perbedaan secara nyata (Tabel 2). Laju pertumbuhan mikrobia tergantung pada ketersediaan nutrisi yaitu kerangka karbon dan $\mathrm{NH}_{3}$. Diduga dalam penelitian ini mikrobia rumen dalam memfermentasikan substrat kekurangan nutrien, atau tidak tersedia secara bersamaan antara kerangka karbon dan $\mathrm{NH}_{3}$, sehingga produksi VFA tidak terjadi perbedaan. Serat kasar yang tinggi menghambat mikrobia dalam mendegradasi kandungan karbohidrat dari pelepah sawit fermentasi tersebut. Pelepah sawit merupakan sumber pakan berserat yang sebagian besar terdiri dari karbohidrat. Karbohidrat pakan di dalam rumen akan didegradasi mejadi glukosa [16,17,18], selanjutnya menghasilkan VFA dengan volume yang cukup tinggi.

Penelitian menunjukkan bahwa konsentrasi VFA pada perlakuan lama fermentasi 28 hari (H2) berbeda nyata $(p<0,05)$ dengan perlakuan lama fermentasi 14 hari (H1). Hal ini disebabkan semakin lama fermentasi memberikan waktu bagi substrat untuk berinteraksi lebih lama dengan enzim mikrobia sehingga meningkatkan produksi VFA. Lamanya substrat berinteraksi dengan mikrobia menunjukkan peningkatan aktivitas isolat mikrobia untuk melakukan 
pertumbuhan dan fermentasi, yang mengakibatkan meningkatnya konsentrasi VFA [5].

Rata-rata produksi VFA pada penelitian ini sebesar $94,75 \mathrm{mM}-126,5 \mathrm{mM}$, masih pada kisaran normal untuk sintesis protein mikrobia yang optimal. Wajizah et al. [12] melaporkan konsentrasi VFA pelepah kelapa sawit yang difermentasi menggunakan aspergillus niger berkisar antara 75,25 sampai dengan 96,58 mM. Harahap et al. [19], melaporkan konsentrasi VFA pelepah sawit yang diamoniasi dan fermentasi menghasilkan VFA sebesar 95,07-131,35 mM. Wajizah et al. [12], melaporkan konsentrasi VFA pelepah sawit fermentasi dengan prolinas berkisar yakni 67,97-90,70 mM.

Pelepah sawit yang difermentasi selama 28 hari (H2) terjadi penurunan produksi protein mikrobia rumen. Semakin banyak level mikrobia rumen kerbau yang ditambahkan, meningkatkan populasi mikrobia dalam substrat. Semakin lama fermentasi, menyebabkan berkurangnya pasokan nutrien dalam substrat yang dapat dimanfaatkan oleh mikrobia. Keadaan yang demikian mengakibatkan terjadinya persaingan antar mikrobia dalam memperebutkan nutrien dalam substrat yang ketersediaannya terbatas, hal ini mengakibatkan jumlah mikrobia yang mati meningkat.

Penurunan populasi mikrobia hidup yang melekat pada pelepah sawit akibat hal di atas, menyebabkan tidak optimalnya mikrobia tersebut dalam membantu mikrobia rumen untuk memanfaatkan nutrien prekusor sintesis protein mikrobia di dalam rumen, seperti $\mathrm{N}$, sulfur, asam lemak rantai panjang, $\mathrm{Zn}$, dan energi. Laju pertumbuhan mikrobia maksimal dicapai jika konsentrasi semua nutrien tersedia secara optimum dalam rumen [21]. Kurang termanfaatkannya nutrien prekusor sintesis protein mikrobia di dalam rumen, mengakibatkan menurunnya aktivitas mikrobia rumen dalam proses tersebut. Hal ini tercermin pada produksi $\mathrm{NH}_{3}$ dan VFA yang tidak bersamaan. Volatile fatty acids (VFA) lebih lambat diproduksi dari pada $\mathrm{NH}_{3}$, karena kandungan karbohidrat struktural pada pelepah sawit fermentasi yang masih tinggi, akibat belum optimalnya perombakan ikatan kompleks (lignoselulosa dan lignohemiselulosa) pelepah sawit menjadi ikatan yang lebih sederhana pada saat proses fermentasi pelepah sawit, sehingga mikrobia rumen membutuhkan waktu yang lebih lama untuk memfermentasikannya menjadi VFA, dan tidak dapat mengimbangi kecepatan produksi $\mathrm{NH}_{3}[22]$. Peningkatan kualitas pelepah sawit terhadap kecernaan nutrien dan produk fermentasi rumen kerbau, sintesis protein mikroba ini disebabkan tersedianya nutrien yang cukup seperti $\mathrm{NH}_{3}$ dan karbohidrat yang mudah terfermentasi (fermentable).

Ketersediaan $\mathrm{NH}_{3}$ harus diikuti oleh produksi VFA total secara bersamaan agar mikrobia rumen dapat memanfaatkan kedua prekusor tersebut secara efisien untuk berlangsungnya proses sintesis protein mikrobia. Amonia $\left(\mathrm{NH}_{3}\right)$ berperan dalam penyediaan sumber $\mathrm{N}$ sedangkan VFA berperan sebagai kerangka karbon (VFA rantai cabang) dan penyedia sumber energi bagi mikrobia rumen pada proses tersebut, yaitu adenosin trifosfat (ATP) yang dihasilkan melalui proses pemecahan glukosa menjadi asam piruvat (glikolisis). Penurunan produksi protein mikrobia rumen pada penelitian ini, terutama pada pelepah sawit yang mendapat perlakuan fermentasi P2 (3\% level isolat mikrobia) dan $\mathrm{H} 2$ (28 hari fermentasi) secara terpisah, masing-masing 15,34 dan $8,02 \mathrm{mg} / \mathrm{ml}$. Sintesis protein mikroba (SPM) ransum yang mengandung serat sawit amoniasi pada berbagai taraf konsentrasi daun ubi kayu 0, 5, 10, 15, dan 20\% mengasilkan protein mikroba masing-masing yakni 16,08, 18,50, 23,56, 30,64 dan 29,81 $\mathrm{mg} / \mathrm{ml} \mathrm{[19].} \mathrm{Perlakuan} \mathrm{fermentasi} \mathrm{dengan}$ menambahkan level isolat mikrobia rumen kerbau hingga 3\% dan difermentasi hingga 28 hari, diduga mengandung sedikit asam amino rantai cabang akibat penurunan populasi mikrobia hidup yang melekat pada pelepah sawit. Kondisi yang ideal untuk proses sintesis protein mikrobia adalah konsentrasi VFA yang diproduksi sama cepat dengan produksi $\mathrm{NH}_{3}$, sehingga pada saat $\mathrm{NH}_{3}$ terbentuk diikuti dengan ketersediaan produk fermentasi asal karbohidrat yang digunakan sebagai sumber energi dan kerangka karbon. Nitrogen yang dibutuhkan 
untuk sintesis mikroba rumen adalah dalam bentuk NH3, asam amino dan peptida. Energi untuk sintesis mikroba rumen adalah dalam bentuk adenosine triphosphate (ATP). Energi dalam bentuk asam lemak terbang (volatile fatty acids/VFA) merupakan sumber energi bagi ruminansia. Hanya VFA berantai cabang yang menyediakan kerangka karbon bagi sintesis protein mikroba rumen [22].

Produksi protein total pada penelitian ini berkisar antara 32,55-39,96 mg/g dengan kadar protein kasar 1,86-2,61\%, Wajizah et al. [12] melaporkan kadar protein kasar pelepah sawit yang difermentasi dengan Aspergilus niger dengan penambahan sumber karbohidrat berbeda sebesar 11,16 sampai $13,25 \%$, dengan rata-rata penngkatan protein kasar sebesar 2,08\%. Produksi protein total yang tinggi pada penelitian ini, diduga disebabkan oleh tingginya fermentabilitas pelepah sawit di dalam rumen menjadi amonia. Amonia yang dihasilkan, secara efisien digunakan sebagai sumber $\mathrm{N}$ untuk sintesis protein tubuh mikrobia, hal ini terutama terlihat pada kombinasi perlakuan fermentasi $\mathrm{P} 1 \mathrm{H} 1$ dan $\mathrm{P} 2 \mathrm{H} 2$. Konsentrasi amonia rumen yang rendah, diduga digunakan untuk proses perkembangbiakan mikrobia rumen sehingga proses fermentasi berjalan baik, atau adanya penurunan asupan $\mathrm{N}$ dan turunnya degradasi protein [23].

Kecernaan bahan kering pada penelitian ini yakni berkisar 37,68\%-41,58\%. Rerata KcBK sejalan dengan hasil kajian [24], sebesar $30,99-46,39 \%$ pada pelepah sawit yang difermentasi dengan berbagai sumber mikroba. Lebih tinggi dari yang dilaporkan [12] pada pelepah kelapa sawit yang difermentasi menggunakan Aspergillus niger yang menghasilkan KcBK sebesar 20,9525,23\%. Harahap et al. [25] melaporkan bahwa pelepah kelapa sawit yang difermentasi menggunakan Trichoderma viride dan Aspergillus niger, masing-masing menghasilkan KcBK 25,71\%, dan 13,31 \%. Hal ini diduga karena hasil NDF (Tabel 1) yang juga tidak terjadi interaksi antara perlakuan level isolat dan lama fermentasi.

Hasil penelitian menunjukkan bahwa rerata KcBK pada lama fermentasi 28 hari (H2) lebih tinggi daripada perlakuan lama fermentasi 14 hari (H1). Tingginya kecernaan bahan kering pada lama fermentasi 28 hari (H2) diduga terjadi perenganggan ikatan lignoselulosa yang lebih mudah didegradasi oleh mikrobia rumen. Lama waktu fermentasi memberikan kesempatan pada mikrobia rumen untuk mendegradasi pelepah sawit semakin tinggi sehingga KcBK meningkat. Lama waktu fermentasi memberikan kesempatan isolat mikrobia dalam melonggarkan ikatan lignoselulosa dan lignohemiselulosa, sehingga KcBK menjadi meningkat. Rendahnya kandungan serat kasar, selulosa dan hemiselulosa memudahkan bakteri untuk melakukan penetrasi ke dalam material pakan untuk proses pencernaan. Perubahan struktur serat mengakibatkan penetrasi enzim yang dihasilkan mikrobia rumen menjadi lebih mudah, sehingga akan meningkatkan KcBK. Proses degradasi melibatkan 3 jenis enzim yang bekerja secara sinergis, yaitu endo- $1,4-\beta$ glucanase dan ekso-1,4- $\beta$-glucanase serta $\beta$ glucosidase. Enzim-enzim tersebut membantu dalam mendegradasi komponen serat, sesuai giliran dari bagian amorf berganti dengan daerah kristalin [26]. Penggunaan jamur dan enzim yang memiliki kemampuan memetabolisme lignoselulosa berpotensi meningkatkan nilai gizi melalui mekanisme delignifikasi yang selektif [27].

Kecernaan bahan organik pada penelitian ini berkisar $41,02 \%-41,76 \%$, lebih tinggi dari kajian [12] KcBO pada pelepah kelapa sawit yang difermentasi menggunakan Aspergillus niger menghasilkan berkisar antara $17,21-21,88 \%$ dan kajian [25] pada pelepah kelapa sawit yang difermentasi menggunakan Trichoderma viride dan Aspergillus niger, masing-masing menghasilkan KcBO 25,11\%, dan 13,74 \%. Wajizah et al. [12], melaporkan KcBK dan KcBO pelepah sawit yang difermentasi dengan prolinas berkisar 28,11$34,04 \%$ dan $28,63-31,64 \%$. [28] menyatakan bahan pakan yang baik memiliki nilai lebih dari $60 \%$. Kecernaan bahan organik akan tinggi jika kadar protein kasar bahan pakan tinggi dan akan rendah jika kandungan serat, baik NDF, ADF maupun hemiselulosa dalam bahan pakan tinggi [29]. 


\section{KESIMPULAN}

Berdasarkan hasil penelitian disimpulkan bahwa, pengolahan pelepah sawit melalui proses fermentasi dengan menggunakan isolat mikrobia selulolitik rumen kerbau mampu meningkatkan nilai nutrien pelepah sawit, fermentabilitas baik produksi $\mathrm{NH}_{3}$, VFA maupun produksi protein mikroba serta meningkatkan kecernaan bahan bahan kering.

\section{KONFLIK KEPENTINGAN}

Kami menyatakan bahwa dalam penulisan artikel ini tidak terdapat konflik kepentingan yang berhubungan dengan keuangan, pribadi, atau lainnya dengan orang atau organisasi lain yang terkait dengan materi yang dibahas dalam naskah.

\section{DAFTAR PUSTAKA}

1. Mathius, W. I. 2008. Pengembangan sapi potong berbasis industri kelapa sawit. Pusat Penelitian dan Pengembangan Peternakan Bogor. Pengembangan Inovasi Pertanian. I(2):206-224.

2. Rahman, M. M., M. Lourenco, H.A. Hassim, J.J.P. Boars, A.S.M. Sonnenberg, J.W. Cone J.W, J. De Boever, and V. Fievez. 2011. Improving ruminal degradability of oil palm fronds using white rot fungi. J. Anim. Feed. Sci. and Tech. 169(4):157-166. Doi: 10.1016/j.anifeedsci.2011.06.014

3. Wanapat, M., R. Pilajun and P. Kongmun. 2009. Ruminal ecology of swamp buffalo as influenced by dietary sources. J. Anim. Feed Sci. and Techn. 151:205-214. Doi: 10.1016/j.anifeedsci.2009.01.017

4. Hanafi N.D., M. Tafsin, dan D.R. Purba. 2018. Isolasi dan karakteristik bakteri lignoselulolitik rumen kerbau sebagai pendegradasi komponen serat. TALENTA Conference Series: Science \& Technology (ST). 1(2):101-108. Doi: 10.32734/st.v1i2.287

5. Muhtarudin dan Liman. 2006. Penentuan tingkat penggunaan mineral organic untuk memperbaiki bioproses rumen pada kambing secara in vitro. Jurusan Produksi Ternak, Fakultas Pertanian Universitas Lampung. Jurnal Ilmu-ilmu Pertanian
Indonesia. 8(2):132-140. Doi: 10.31186/jipi. 8.2.132-140

6. Pamungkas, D., R. Utomo, N. Ngadiyono, dan M. Winugroho. 2010. Supplementing energy and protein source at different rate of degradability to mixture of corn waste and coffee pod as basal diet on rumen fermentation kinetic of beef cattle. J. Anim. and Vet. Sci. 15(1):22-30. Doi: 10.14334/ jitv.v15i1.674

7. Ani, A.S., R. I. Pujaningsih, dan Widiyanto. 2015. Perlindungan protein menggunakan tannin dan saponin terhadap daya fermentasi rumen dan sintesis protein mikroba. J. Veteriner. 16(3):439-447.

8. Bachrudin, Z., A.S.M. Sofro and B.I.M. Tampoebolon. 1998. The characterization of cellulase produced by buffalo rumen microbe: determination of michaleis constantas ( $\mathrm{Km}$ and maximum velocity $(\mathrm{Vm})$ ). Indonesian Journal of Biotechnology. 6:185-188.

9. AOAC. 2016. Official methods of analysis of the association of analytical chemist. 20th Ed. Assoc of Offi. Anal. Chem. MARYLAND USA.

10. Tilley, J.M.A. dan R.A. Terry. 1963. A two stage technique for the in vitro digestion of forage crops. J. Br. Grsld. Soc. 18:104-111. Doi: 10.1111/j.1365-2494.1963.tb00335.x

11. Departement of Dairy Science. 1996. General Laboratory Procedures. University of Winconsin, Madison.

12. Wajizah, S., Samadi, Y. Usman, dan E. Mariana. 2015. Evaluasi nilai nutrisi dan kecernaan in vitropelepah kelapa sawit (oil palm fronds) yang difermentasi menggunakan aspergillus niger dengan penambahan sumber karbohidrat yang berbeda. J. Agripet. 15(1):13-19.

13. Mardalena, S. Syarif dan Akmal. 2016. Efek pemberian pelepah sawit yang difermentasi dengan prolinas terhadap karakteristik rumen sapi perah PFH. J. Ilmiah Ilmu-Ilmu Peternakan. 19(2):55-62. Doi: 10.22437/jiiip.v19i2.3846

14. Yuan, Z. Q., S. X. Tang, B. Zeng, M. Wang, Z. L. Tan, Z. H. Sun, C. S. Zhou, X F Han, and M. A. Bamikole. 2010. Effects of dietary supplementation with alkyl polyglycoside, a nonionic surfactant, on nutrient digestion and ruminal fermentation in goats. J. 
Anim. Sci. 88: 3984-3991. doi: 10.2527/jas. 2009-2397

15. Marhaeniyanto, E. dan S. Susanti. 2018. Fermentabilitas ruminal secara in vitro suplementasi tepung daun gamal, kelor, randu dan sengon dalam konsentrat hijau. Jurnal Ilmu-Ilmu Peternakan 28 (3):213223. Doi: 10.21776/ub.jiip.2018.028.03.04

16. Adriani dan Mushawir. 2009. Kadar glukosa darah, laktosa dan produksi susu sapi perah pada berbagai tingkat suplementasi mineral makro. J. Ind. Trop. Animal Agri. 34(2):88-96.

17. Hindratiningrum, N., M. Bata dan S. A. Santosa. 2011. Produk fermentasi rumen dan produksi protein mikroba sapi lokal yang diberi pakan jerami amoniasi dan beberapa bahan pakan sumber energi. J. Agripet, 11(2):29-34. Doi: 10.17969/ agripet.v11i2.371

18. Araujo, A.P.C., B.C. Venturelli, M.C.B. Santos, R. Gardinal, N.R.B. Consolo, G.D. Calomeni, J.E. Freitas, R.V. Barletta, J.R. Gandra, P.G. Paiva, and F.P. Renno,. 2015. Chitosan affects total nutrient digestion and ruminal fermentation in Nellore steers. Anim. Feed. Sci. and Tech. 206:114-118. Doi: 10.1016/j.anifeedsci.2015.05.016

19. Harahap N. , E. Mirwandhono, dan N. D. Hanafi. 2017. Uji Kecernaan Bahan Kering, Bahan Organik, Kadar Nh3 Dan Vfa Pada Pelepah Daun Sawit Terolah Pada Sapi Secara In Vitro. Jurnal Peternakan. 1(1):1321.

20. Rodríguez R., A. Sosa and Y. Rodríguez. 2007. Microbial protein synthesis in rumen and its importance to ruminants. Cuban Journal of Agricultural Science. 41(4):287294.

21. Syapura, M. Bata dan W. S. Pratama. 2013. Peningkatan kualitas jerami padi dan pengaruhnya terhadap kecernaan nutrien dan produk fermentasi rumen kerbau dengan feces sebagai sumber inoculum. J. Agripet. 13(2):59-67. Doi: 10.17969/agripet. v13i2.822

22. Anggraeny, Y. N., H. Soetanto, Kusmartono dan Hartutik. 2015. Sinkronisasi suplai protein dan energi dalam rumen untuk meningkatkan efisiensi pakan berkualitas rendah. Wartazoa. 25(3):107-116. Doi: 10.14334/ wartazoa.v25i3.1155

23. Ramos, S., M. L. Tejido, M.E M. J. Ranill and M. D. Carro. 2009. Microbial protein synthesis, ruminal digestion, microbial populations, and nitrogen balance in sheep fed diets varying in forage-to-concentrate ratio and type of forage. J. Anim. Sci. 87:2924-2934. Doi: 10.2527/jas.2009-1938

24. Astuti, T. dan G. Yelni. 2015. Evaluasi kecernaan nutrient pelepah sawit yang difermentasi dengan berbagai sumber mikroorganisme sebagai bahan pakan ternak ruminansia. J. Sain Peternakan Indonesia. 10(2):101-106. Doi: 10.31186/ jspi.id.10.2.101-106

25. Harahap, N., E. Mirwandhono dan N. D. Hanafi. 2017. Uji kecernaan bahan kering, bahan organik, kadar NH3 dan VFA pada pelepah daun sawit terolah pada sapi secara in vitro. Jurnal Peternakan. 1(1):1321. Doi: 10.31604/jac.v1i1.209

26. Aminah S, L. K. Nuswantara, B. I. M. Tampoebolon, dan Sunarso. 2020. Peningkatan Kualitas Sabut Kelapa Melalui Teknologi Fermentasi Menggunakan Mikroba Pencerna Serat Terseleksi dari Cairan Rumen Kerbau. Sains Peternakan. 18(1):44-52. Doi: 10.20961/sainspet.v\%vi\%i.35976.

27. Yanuartono, H. Purnamaningsih, S. Indarjulianto dan A. Nururroz. 2017. Potensi jerami sebagai pakan ternak ruminansia. Jurnal Ilmu-Ilmu Peternakan. 27(1):40-62. Doi: 10.21776/ub.jiip.2017.027. 01.05

28. Fathul, F. dan S. Wajizah. 2010 Penambahan mikromineral $\mathrm{Mn}$ dan $\mathrm{Cu}$ dalam ransum terhadap aktivitas biofermentasi rumen domba secara in vitro. Jurnal Ilmu Ternak dan Veteriner. 15(1):9-15.

29. Jayanegara, A., A. Sofyan, H.P.S. Makkar dan K. Becker. 2009. Kinetika produksi gas, kecernaan bahan organik dan produksi gas metana in vitro pada hay jerami yang disuplementasi hijauan mengandung tanin. Media Peternakan. 32(2):120-129. 